\title{
Efeitos do Transcurso do Tempo e a Polêmica sobre a Prescrição das Multas nos Tribunais de Contas: a aplicação da Lei n. 9.873/1999 por analogia
}

\author{
Effects of the Passage of Time and the Controversy Over the Fines's \\ Limitation of Action in Courts of Accounts: the application of Law $\mathbf{n}$. \\ $9.873 / 1999$ by analogy
}

\author{
Marcos Ehrardt Junior ${ }^{1}$ \\ ${ }^{1}$ Universidade Federal de Alagoas - Maceió - AL, Brasil.
}

\author{
Ricardo Schneider Rodrigues ${ }^{2}$ \\ ${ }^{2}$ Centro Universitário Cesmac - Maceió - AL, Brasil.
}

\begin{abstract}
Resumo: O objetivo deste artigo é definir se a cominação de multa pelos Tribunais de Contas está sujeita à prescrição e, em caso positivo, indicar qual seria o regime jurídico aplicável à hipótese de inexistência de norma jurídica (lacuna). O método de abordagem é baseado no raciocínio dedutivo, a partir de pesquisa de natureza qualitativa e teórico-prática, tendo por objeto uma pesquisa bibliográfico-documental. A conclusão indica que, por analogia legis, a fiscalização dos Tribunais de Contas deve se submeter às normas de direito público mais próximas e que regulamentem em todos os aspectos a questão da prescrição, prevista na Lei n. $9.873 / 1999$.
\end{abstract}

Palavras-chave: Tribunal de Contas. Multa. Prescrição.
Abstract: The purpose of this article is to determine if the fine application by the Courts of Accounts is subject to some limitation of action period and, if so, indicate the legal regime applicable to the hypothesis of nonexistence of a legal rule about it. The method of approach is based on deductive reasoning, based on qualitative and theoretical-practical research, with the object of a bibliographicdocumentary research. The conclusion indicates that, by analogy legis, the supervision of TCs should be subject to the closest public law norms and that regulate in all aspects the issue of prescription, provided for in Law n. 9,873/99.

Keywords: Court of Accounts. Fine. Limitation of Action.

Recebido em: 21/12/2017

Revisado em: 18/07/2018

Aprovado em: 27/07/2018 


\section{Introdução}

O problema do decurso do tempo sem a manifestação dos Tribunais de Contas (TCs) costuma suscitar diversos questionamentos pelos gestores públicos, muitas vezes inconformados com a atuação tardia do órgão de fiscalização. Em razão disso, diversas Cortes de Contas no Brasil têm se deparado com controvérsias relacionadas à disciplina do prazo prescricional e decadencial aplicável no âmbito de suas atividades de controle externo, como demonstram diversas demandas judiciais relacionadas ao tema.

O Supremo Tribunal Federal (STF) já reconheceu a repercussão geral da questão da prescritibilidade da pretensão de ressarcimento ao erário fundada em decisão de Tribunal de Contas (2016b). Em outro caso, foi ajuizada a Ação Direta de Inconstitucionalidade (ADI) n. 5.259, sobre artigos da Lei Complementar n. 588, do Estado de Santa Catarina, que estabeleceu o prazo de cinco anos para análise e julgamento de todos os processos administrativos relativos a administradores e demais responsáveis submetidos ao controle do Tribunal de Contas (TC) local ${ }^{1}$.

Em abril de 2016, o Procurador-Geral da República ajuizou a ADI n. 5.509, acerca de diversos dispositivos da Constituição do Estado do Ceará, que instituíram, no âmbito do Tribunal de Contas do Estado, os institutos da prescrição e da decadência, com prazo de cinco anos, ao argumento de que tal previsão violaria a cláusula de imprescritibilidade do artigo 37, §5º da Constituição da República (BRASIL, 1988).

Em julgado de novembro de 2016, o Supremo Tribunal Federal (STF) declarou a inconstitucionalidade de dispositivo da Constituição de Sergipe que estipulava o prazo de 180 dias para apresentação do parecer prévio pelo Tribunal de Contas local (BRASIL, 2016a)². Em caso semelhante a este, foi

\footnotetext{
${ }^{1} \mathrm{Na}$ referida demanda, o Ministério Público Federal, autor da ação, manifestou-se pela declaração de inconstitucionalidade parcial sem redução de texto, no Parecer n. 182.786/2015-AsJConst/SAJ/PGR, a fim de afastar do campo de incidência dos prazos prescricionais os procedimentos administrativos da competência do Tribunal de Contas Estadual que visem, direta ou indiretamente, ao ressarcimento de danos causados ao erário (BRASIL, 2015).

${ }^{2}$ A norma objeto do controle de constitucionalidade estabelecia que, decorrido o prazo sem manifestação, seria permitido às Câmaras Municipais proceder ao julgamento das
} 
ajuizada, pela Associação dos Membros dos Tribunais de Contas do Brasil (ATRICON), a Ação de Arguição de Descumprimento de Preceito Fundamental n. 434, em face da atuação da Assembleia Legislativa de Alagoas, que, diante da demora do órgão de controle no desempenho de suas funções, aprovou diversas prestações de contas do então Governador do Estado sem que houvesse a manifestação prévia do TC.

A questão temporal também repercutiu sobre a competência das Cortes de Contas quanto ao exame de legalidade e registro dos atos de aposentadoria, pensão e reforma ${ }^{3}$. No julgado mais recente do STF, de março de 2017, a Corte enfrentou o tema da prescrição em relação às multas aplicadas pelo Tribunal de Contas da União (TCU), diante da lacuna normativa sobre o prazo para o exercício da pretensão punitiva (BRASIL, 2017a).

As consequências jurídicas que a omissão dos Tribunais de Contas pode gerar comportam, portanto, diversas análises. É possível observar a questão do ponto de vista das Cortes que já possuem normas expressas tratando do tema, como visto no caso de Santa Catarina e do Ceará, ou daquelas onde ainda há lacuna normativa, como o ocorre, por exemplo, no Tribunal de Contas da União e no Tribunal de Contas do Estado de Alagoas.

Também é pertinente o exame da omissão conforme a competência exercida pelo $\mathrm{TC}$, se relativa à emissão de parecer prévio, julgamento de contas, registro do ato de aposentadoria, pensão, reforma ou admissão de pessoal, ou ainda se em processo voltado à apuração de dano ao erário ou à aplicação de multa em decorrência do descumprimento de alguma determinação da Corte (competência sancionatória). São várias as possi-

contas dos respectivos Prefeitos, independentemente da atuação prévia da Corte de Contas.

${ }^{3}$ A Suprema Corte (2007) adota o entendimento de que o contraditório e ampla defesa não precisam ser observados nos referidos processos, por se tratar de ato complexo. Contudo, o STF (2014) flexibilizou tal compreensão e passou considerar que, passados mais de cinco anos desde o recebimento do ato concessivo pelo TC, sem a devida apreciação, embora não seja o caso de decadência, nos termos do artigo 54 da Lei n. 9.784, de 1999, passa a ser obrigatória a oitiva do interessado, caso venha a ser detectada alguma irregularidade. 
bilidades de enfrentamento do fenômeno, que nem sempre encontra tratamento adequado em nossa doutrina.

É necessário, portanto, delimitar a abordagem dos efeitos jurídicos decorrentes do referido fato jurídico. Neste trabalho, o objetivo consiste especificamente em definir se a cominação de multa pelos Tribunais de Contas está sujeita à prescrição, em razão da inércia da Corte, bem como, em caso positivo, indicar qual seria o regime jurídico aplicável à hipótese de inexistência de norma jurídica expressa dispondo sobre o prazo prescricional.

Nesta pesquisa, o método de abordagem será baseado no raciocínio dedutivo, partindo-se de ideias e conceitos amplos e gerais, para deles extrair consequências menos universais (MEZZAROBA; MONTEIRO, 2014, p. 91-94; FINCATO, 2014, p 42). É necessário, inicialmente, compreender como o Tribunal de Contas atua e o conceito de prescrição comum aos diversos ramos do Direito - para se chegar ao cerne do problema e apresentar uma resposta satisfatória. Para tal fim, a pesquisa terá natureza qualitativa e teórico-prática, buscando-se a análise descritiva dos fatos conjugada com o exame de sua natureza e possíveis interpretações a respeito do fenômeno estudado, baseando-se tanto na teoria como na atuação prática do TCU e do STF (MEZZAROBA; MONTEIRO, 2014, p. 134-142). Em relação ao objeto, trata-se de pesquisa bibliográfico-documental, focada em livros e artigos científicos relacionados ao tema (bibliográfica), bem como na análise de documentos que ainda não receberam tratamento analítico (documental), como é o caso das decisões do TCU e do STF (FINCATO, 2014, p. 49-51).

Destarte, para o deslinde da questão será analisada, inicialmente, a competência sancionatória dos Tribunais de Contas e o fenômeno da prescrição, a partir do ponto de vista teórico e bibliográfico. Em seguida, será estudado como o tema vem sendo decidido no âmbito do TCU e do STF e os argumentos por eles utilizados, na perspectiva prática e documental. A escolha do Tribunal de Contas da União justifica-se pelo fato de a própria Constituição atribuir-lhe a qualidade de paradigma em relação aos Tribunais de Contas estaduais (BRASIL, 1988, art. 75) e a do STF por exercer, corriqueiramente, o controle sobre a atuação do TCU, por força 
da competência estabelecida no artigo 102, inciso I, "d", da Constituição. Além disso, o TCU pacificou a questão ora analisada, em sede de incidente de uniformização de jurisprudência (2016), de forma contrária ao entendimento recentemente apresentado pelo STF (BRASIL, 2017a). Ao final, será abordada a questão da colmatação da lacuna normativa no âmbito do Direito Público, a partir dos conceitos e análises desenvolvidos nas seções precedentes, para, a partir do método dedutivo, indicar uma resposta satisfatória ao problema ora suscitado.

\section{A Competência Sancionatória dos Tribunais de Contas e a Im- prescindibilidade de Limite um Temporal para Punir}

Os Tribunais de Contas não ocupam um papel facilmente adequável à clássica tripartição dos poderes (ou funções) do Estado. Embora auxiliem o Poder Legislativo não são órgão dele, pois desempenham funções próprias e exclusivas. Não são subordinados a qualquer dos três Poderes clássicos, mas possuem autonomia administrativa, financeira e orçamentária. Sua estrutura orgânica e o regime jurídico de seus membros têm como parâmetro o Poder Judiciário (art. 73, caput, parte final, e $\S \S 3^{\circ} \mathrm{e}$ $4^{\circ}$ ), inclusive com a previsão de um Ministério Público especial atuando junto à Corte (BRASIL, 1988, art. 130), característica única e não verificada em nenhum outro órgão do Estado, além do próprio Poder Judiciário. Entretanto, tampouco integram o Poder Judiciário, por escolha própria do Constituinte, ${ }^{4}$ embora exerçam, apenas em relação à competência do inciso II do artigo 71 da Constituição, parcela da jurisdição ${ }^{5}$.

Por todas essas razões e, também, por ser o órgão por excelência de fiscalização dos gestores públicos, não integram o Poder Executivo e, por

\footnotetext{
${ }^{4}$ Em Portugal, o Tribunal de Contas integra o Poder Judiciário (art. 209.1, c).

5 "Duas exceções admite a Constituição ao monopólio jurisdicional do Poder Judiciário, no que concerne à matéria contenciosa administrativa. A primeira diz respeito aos crimes de responsabilidade do Presidente da República, dos Ministros de Estado, quando conexos com os desse, e dos Ministros do Supremo Tribunal Federal. O seu julgamento competirá ao Congresso. A segunda se refere ao julgamento da regularidade das contas dos administradores e demais responsáveis pela guarda ou aplicação de bens ou fundos públicos atribuídos ao Tribunal de Contas". (FAGUNDES, 2005, p. 167)
} 
conseguinte, a administração pública. Trata-se, como bem asseverado por Pontes de Miranda (1973, p. 248), de um órgão sui generis do Poder Judiciário e do Poder Legislativo, “[...] criação posterior à teoria da separação dos poderes e fruto da prática, destoava das linhas rígidas da repartição". À luz do texto constitucional de 1946, destaca que "[...] no plano material era corpo judiciário, no formal, corpo auxiliar do Congresso Nacional" (MIRANDA, 1973, p. 248). Com razão, no ponto, Ayres Britto (2005, p. 2), ao asseverar que se trata de instituição autônoma e independente, não pertencente a nenhum dos três Poderes, tal como o Ministério Público.

De igual modo, não é possível caracterizar os processos de contas especificamente como administrativos, jurisdicionais ou legislativos porque possuem ontologia própria (BRITTO, 2005). Uma de suas peculiaridades consiste na denominada tridimensionalidade, cujas dimensões são a política, a indenizatória e a sancionatória (CAVALCANTI, 1999).

Em sua dimensão de natureza política, o processo de contas proporciona a realização do ideal republicano de informar o povo quanto à gestão pública, por ser assegurado constitucionalmente o direito de a sociedade conhecer como se deu a utilização dos recursos públicos. Aqui temos como destinatário principal do processo a coletividade e apenas de forma secundária o gestor. $\mathrm{Na}$ dimensão de natureza indenizatória almeja-se a reparação pelo prejuízo causado ao erário, sendo possível alcançar até os sucessores, na medida do patrimônio transferido (BRASIL, 1988, art. $\left.5^{\circ}, \mathrm{XLV}\right)$. Por fim, em sua dimensão sancionatória, são aplicadas as sanções pela má gestão, cuja sede está no artigo 71, inciso VIII, da Constituição da República.

A Constituição autoriza a aplicação de diversas sanções em caso de ilegalidade de despesa ou de irregularidade de contas, não restritas apenas às multas. Ocorre que para o exame da legalidade de despesa ou da regularidade de contas é imprescindível que o gestor público forneça ao controle externo todas as informações indispensáveis à sua atuação. Isto é decorrência lógica do princípio da prestação de contas, cuja inobservância autoriza até a excepcional intervenção de um ente federativo em outro (artigos 34, inc. VII, “d”, e 35, inc. II, da Constituição da República). O parágrafo único do artigo 70 e o artigo 75 do texto constitucional esta- 
belecem claramente o dever de prestar contas para qualquer pessoa física ou jurídica, pública ou privada, que utilize, arrecade, guarde, gerencie ou administre dinheiros, bens e valores públicos ou pelos quais a União, Estados, Distrito Federal e Municípios respondam, ou que, em nome destes, assuma obrigações de natureza pecuniária. Disso decorrem os dispositivos do artigo 113 da Lei n. 8.666/936 e do artigo 93 do Decreto-Lei n. $200 / 67^{7}$, que exigem dos gestores públicos a demonstração da legalidade e da regularidade das despesas e execução, bem como a justificativa do bom e regular emprego dos recursos públicos.

Dessa forma, há amparo constitucional na previsão em lei de multa a ser aplicada em face de gestor público que, por exemplo, não atenda regularmente às obrigações ínsitas ao dever de prestar contas, dentre as quais a de prestar tempestivamente as informações cobradas pelos órgãos de controle externo, além de várias outras previstas em lei. Nessa toada, temos a previsão legal de aplicação de multas pelo Tribunal de Contas da União, nos artigos 57 e seguintes da Lei Federal n. 8.443/1992, e pelos demais Tribunais de Contas do Brasil, em suas respectivas leis orgânicas, que delimitam expressamente a conduta, o valor da penalidade e seus parâmetros de aplicação.

O rol de competências estabelecido pelo constituinte originário não pode ser mitigado pelo legislador infraconstitucional. No entanto, é possível - e até recomendável - a ampliação de suas competências, por meio de lei, para que as Cortes de Contas possam melhor cumprir seu papel constitucional. Nesse sentido, o Supremo Tribunal Federal reconhece, por exemplo, a despeito da inexistência de previsão expressa na Constituição, o poder geral de cautela dos Tribunais de Contas (2004). Outro exemplo de competência não prevista na Constituição, mas que vai ao encontro do

\footnotetext{
${ }^{6}$ Art. 113. O controle das despesas decorrentes dos contratos e demais instrumentos regidos por esta Lei será feito pelo Tribunal de Contas competente, na forma da legislação pertinente, ficando os órgãos interessados da Administração responsáveis pela demonstração da legalidade e regularidade da despesa e execução, nos termos da Constituição e sem prejuízo do sistema de controle interno nela previsto.

${ }^{7}$ Art. 93. Quem quer que utilize dinheiros públicos terá de justificar seu bom e regular emprêgo na conformidade das leis, regulamentos e normas emanadas das autoridades administrativas competentes.
} 
ideal de propiciar a essas Cortes os instrumentos necessários para a sua atuação, são as consultas, cuja previsão está consignada no artigo $1^{\circ}$, inciso XVII, da Lei n. 8.443/1992. Com efeito, “[...] desde que respeitados os limites da competência ratione materiae, é possível alargar as atribuições das Cortes de Contas, em ordem a que possam melhor desempenhar suas funções.” (FERRAZ, 2002, p. 4).

Destarte, definida a possibilidade de os Tribunais de Contas aplicarem multas aos seus jurisdicionados, na forma da lei, surge a questão relacionada ao prazo para atuação das Cortes. A Constituição estabelece, em caráter excepcional, a possibilidade de penas ou pretensões imprescritíveis, como ocorre claramente nos casos de racismo e da ação de grupos armados, civis ou militares, contra a ordem constitucional e o Estado Democrático (BRASIL, 1988, art. 5º inc. XLII e XLIV), bem como, não sem controvérsias ${ }^{8,}$ no caso ilícitos praticados por qualquer agente, servidor ou não, que causem prejuízos ao erário (BRASIL, 1988, art. 37, § 5º).

É insustentável, portanto, afirmar que, por ausência de regra expressa a definir um prazo para atuar, seria admissível a aplicação de penalidades a qualquer tempo, posto que isto equivaleria a instituir penas imprescritíveis sem qualquer amparo no texto constitucional. Quanto a este aspecto - da necessidade de delimitação de um prazo prescricional - não divergem o TCU e o STF. A questão que surge consiste justamente em definir, diante de lacuna normativa, qual o regime jurídico aplicável aos casos prescrição relacionados ao exercício da competência sancionatória pelos Tribunais de Contas.

O Tribunal de Contas da União e o Supremo Tribunal Federal debruçaram-se sobre o tema recentemente. Antes de analisar tais entendimentos, convém aprofundar, no plano teórico, o conceito de prescrição e suas regras gerais.

\footnotetext{
${ }^{8}$ Recentemente, o STF entendeu que a regra do art. $37, \S 5^{\circ}$, da CR, não alcança os fatos lícitos, definindo a tese de que é prescritível a ação de reparação de danos à Fazenda Pública decorrente de ilícito civil (BRASIL, 2016b).
} 


\section{Considerações Gerais sobre o Fenômeno da Prescrição}

O tempo cronológico tem considerável importância no mundo jurídico. Os institutos jurídicos da prescrição e da decadência são fundamentais em qualquer sistema jurídico, na medida em asseguram tranquilidade na ordem jurídica, afinal, dormientibus non sucurrit jus, isto é, o direito não socorre aos que dormem. A duração dos efeitos, a perda e aquisição dos direitos dependem, muitas vezes, de seu transcurso; afinal, o Direito, enquanto ferramenta destinada a garantir paz e estabilidade no convívio social, necessita consolidar determinadas situações de modo a garantir segurança no relacionamento negocial entre os sujeitos de direito.

$\mathrm{Na}$ teoria dos fatos jurídicos, os institutos da prescrição e da decadência são enquadrados dentro da categoria dos atos-fatos jurídicos, pois o suporte fático de ambos é constituído de forma semelhante, conjugando a inação (=inércia) do titular da pretensão em exercê-la durante certo lapso de tempo, definido pelo sistema jurídico. Ou seja, diante do resultado (transcurso do tempo definido em lei ou contrato), abstrai-se qualquer relevância do elemento volitivo em sua origem, não importando o motivo e se houve (ou não) vontade de não tomar nenhuma providência dentro do prazo cominado, o que interessa é a consumação do lapso temporal previsto e os efeitos daí decorrentes.

Tradicionalmente a doutrina costuma distinguir os institutos da prescrição e da decadência levando em consideração os efeitos que produzem em determinada relação jurídica. Nada obstante, tal opção não apresenta uma verdadeira distinção substancial entre eles, razão pela qual merece destaque a contribuição doutrinária de Agnelo Amorim Filho (1997), que leva em consideração as diferentes categorias de direitos subjetivos para distinguir os conceitos, distanciando-se da clássica discussão acerca da diferenciação entre direito e ação, enquanto elementos de uma relação jurídica.

Para o referido autor, estariam sujeitos à prescrição somente os direitos que ensejassem ações de natureza condenatória, ou seja, aquelas em que se pretende a imposição ao cumprimento de uma prestação, pois a "[...] prescrição é a extinção da pretensão à prestação devida" (GONÇALVES, 2007 , p. 468). De fato, os direitos prestacionais dependem de ato do sujei- 
to passivo, logo estão sujeitos ao inadimplemento (=violação pretensão) e as ações de natureza condenatórias são o meio através do qual se protegem judicialmente os direitos que irradiam pretensões.

Já o emprego da decadência dependeria de direitos potestativos, vale dizer, direitos sem pretensão ou direitos sem prestação, insuscetíveis de violação, que costumam dar origem a ações de natureza constitutiva ou desconstitutiva (GONÇALVES, 2007, p. 468). Enquanto nos direitos a uma prestação o titular depende da cooperação do sujeito passivo para exercer seu direito subjetivo, "[...] nos direitos potestativos, esse exercício independe de qualquer ato do sujeito passivo na medida em que não há prestação a ser por este cumprida.” (THEODORO JÚNIOR, 2007, p. 227).

Via de regra, de modo impreciso e sem rigor técnico, os doutrinadores em geral apenas ressaltavam que a prescrição implicaria perecimento do "direito de ação" enquanto da decadência resultaria o perecimento do próprio direito. Para Marcos Bernardes de Mello (2007, p. 138, grifos nossos), no entanto:

Os atos-fatos da decadência, terminologia adotada pelo Código Civil em lugar de caducidade, e da prescrição, embora se assemelhem em razão da circunstância de terem suportes fácticos com a mesma configuração: inação do titular da pretensão e da ação em exercê-las durante um certo lapso de tempo [...] diferem, substancialmente, quanto à eficácia jurídica, a saber: (a) A decadência tem efeito extintivo sobre o direito subjetivo, decorrendo daí, a extinção da pretensão e da ação dele derivadas. [...] (b) A prescrição não extingue coisa alguma, mas, tão somente, encobre a eficácia da pretensão, da ação e/ou exceção geradas pelo direito. Por consequência, o direito subjetivo continua a existir incólume, mas tem encoberta as suas exigibilidade e impositividade representadas pela pretensão e pela ação, respectivamente, bem assim a oponibilidade da exceção de direito material.

Prestigiando o princípio da operabilidade o legislador do Código Civil vigente tratou de simplificar o modo de distinção entre os institutos, pois enumerou taxativamente todas as hipóteses de prescrição nos artigos 
205 e 206 do texto legal, motivo pelo qual qualquer referência em outro dispositivo do Código será sempre relativa à decadência.

No que concerne aos prazos prescricionais, deve-se também atentar para os dispositivos que disciplinam situações de impedimento, suspensão e interrupção do prazo prescricional antes de sua consumação. O legislador não fez distinção entre os motivos ensejadores do impedimento e da suspensão, que são tratados indistintamente nos artigos 197 a 199. Se o prazo não começou a fluir, e se verificar uma das situações descritas nos artigos mencionados, tem-se um caso de impedimento. Entretanto, após o início da contagem do prazo dá-se a suspensão, cujas consequências devem ser bem esclarecidas para evitar confusão com as hipóteses de interrupção previstas no artigo 202.

Anote-se que os prazos de prescrição não podem ser alterados por acordo das partes. Além disso, só após sua consumação será possível renunciar à prescrição, ou seja, permitir que o credor prossiga exigindo débito cuja pretensão já não tem mais eficácia. Para tanto, o artigo 191 estabelece como condição que a renúncia só valerá sendo feita, sem prejuízo de terceiro, não importando a forma de sua manifestação, já que pode se verificar de modo expresso ou tácito, quer dizer, quando se presume de fatos do interessado, incompatíveis com a prescrição. Importe destacar apenas que a renúncia antecipada não é permitida. A prescrição corre sem ligação subjetiva à titularidade do direito (LÔBO, 2009, p. 344), razão pela qual se iniciada a contagem do prazo contra uma pessoa continua a correr contra o seu sucessor (art. 196).

Se é verdade que a prescrição pode ser interrompida por qualquer interessado, deve-se lembrar que a interrupção da prescrição por um credor não aproveita aos outros, tampouco prejudica aos demais coobrigados (mas a interrupção produzida contra o principal devedor prejudica o fiador), sendo necessário destacar, na hipótese de solidariedade entre os figurantes do negócio (art. 204), o seguinte: (a) a interrupção por um dos credores solidários aproveita aos outros; assim como a interrupção efetuada contra o devedor solidário envolve os demais e seus herdeiros. (b) A interrupção operada contra um dos herdeiros do devedor solidário não 
prejudica os outros herdeiros ou devedores, senão quando se trate de obrigações e direitos indivisíveis.

A solidariedade também opera consequências importantes dentre as causas suspensivas, pois, conforme dispõe o artigo 201, suspensa a prescrição em favor de um dos credores solidários, só aproveitam os outros se a obrigação for indivisível.

Nas páginas anteriores, tem-se um breve resumo do tratamento conferido à prescrição na Teoria Geral do Direito Privado, empregado, em regra, de modo supletivo pelos demais ramos quando necessário disciplinar situações não previstas expressamente em lei. Esta, inclusive, é a posição adotada no âmbito do Tribunal de Contas da União, conforme veremos a seguir.

\section{A Concepção Adotada pelo TCU: aplicação das regras gerais de direito privado}

O Tribunal de Contas da União possuía entendimentos divergentes quanto ao tema da prescrição da pretensão punitiva no âmbito de suas atribuições, diante da ausência de disposição legal acerca da matéria. Eram três as teses suscitadas. A primeira pela imprescritibilidade até a superveniência de regra expressa definindo o prazo e seus marcos interruptivos e suspensivos. A segunda era favorável à aplicação das regras de Direito Público, dada a natureza das atividades da Corte. A terceira defendia a aplicação do Código Civil, cujas disposições, conforme já anotado acima, constituem a regra geral aplicável aos casos de lacuna normativa.

Em sede de incidente de uniformização de jurisprudência, o TCU (2016) consolidou seu posicionamento no sentido da utilização do prazo prescricional geral previsto no Código Civil (CC) e da adoção das respectivas hipóteses interruptivas do seu transcurso. Assim, para a Corte, a pretensão punitiva subordina-se ao prazo geral de prescrição de dez anos, indicado no artigo 205 da Lei n.10.406/2002 (Código Civil). Sua contagem ocorre a partir da data do surgimento da irregularidade sancionada, nos termos do artigo 189 do CC. 
Além disso, para o TCU, o ato que ordena a citação, a audiência ou oitiva da parte tem o condão de interromper a prescrição da pretensão punitiva, nos termos do art. 202, inciso I, do CC, cujo prazo deve recomeçar a contar da data do ato que motivou a interrupção, por força do artigo 202, parágrafo único, parte inicial, do Código Civil.

Ademais, a suspensão da prescrição da pretensão punitiva ocorre, nos termos do referido entendimento, toda vez que a parte apresentar elementos adicionais de defesa ou quando forem necessárias diligências em razão de algum fato novo trazido por ela, não suficientemente documentado nas manifestações processuais. A paralisação da contagem do prazo prescricional deve ocorrer no período compreendido entre a juntada dos elementos adicionais de defesa ou da peça contendo o fato novo e a análise dos referidos elementos ou da resposta à diligência. Por fim, entendeu-se que a ocorrência da prescrição da pretensão punitiva do TCU deve ser aferida independentemente de alegação da parte, em cada processo em que haja intenção de aplicação das sanções previstas em sua Lei Orgânica.

Esse entendimento vem sendo reiterado pela Corte em diversos julgados recentes, afastando expressamente o regime da prescrição previsto na Lei n. 9.784/1999, que versa sobre o processo administrativo federal (2017a; 2017c). Além do argumento pertinente ao caráter de regra geral atribuído às normas do Código Civil, o TCU também vem recusando a aplicação das normas da Lei n. 9.873, de 23 de novembro de 1999, que estabelece prazo de prescrição para o exercício de ação punitiva pela administração pública federal, sob o fundamento de que a atividade de controle exercida pelo TCU não se enquadraria como exercício do poder de polícia do Estado, não cabendo, pois, a sua utilização, nem mesmo por analogia (BRASIL, 2017b).

Não obstante a posição adotada, o TCU tem recebido críticas por parte da doutrina, sob o argumento de que a aplicação de normas de direito privado pelos Tribunais de Contas seria equivocada, diante da autonomia científica do direito administrativo, bem como pela existência de diversas normas de direito público apontando em sentido diverso, adotando o prazo prescricional quinquenal. A seguir abordaremos esse outro 
entendimento, a começar pelo posicionamento sufragado no âmbito do Supremo Tribunal Federal.

\section{A Concepção Adotada pelo STF: aplicação das regras de direi- to público (Lei n. 9.873/1999)}

O Supremo Tribunal Federal, em julgado recente, apreciou mandado de segurança impetrado em face de acórdão do TCU, que aplicou multa pecuniária fundada no artigo 58, inciso II, da Lei n. 8.443/1992 (BRASIL, 2017a). Na ocasião, a Corte enfrentou pela vez primeira a questão do prazo prescricional para o exercício da competência sancionadora pelo TCU, diante da lacuna normativa observada em sua Lei Orgânica (Lei n. $8.443 / 1992)^{9}$.

Ao reconhecer ser praticamente incontroversa a necessidade de limitação temporal do exercício da referida competência, sendo a prescritibilidade a regra em qualquer ramo jurídico, a Primeira Turma do STF, nos termos do voto do Relator, decidiu em favor da aplicação integral da Lei n. 9.873/1999 à prescrição da pretensão sancionatória do TCU, por dois fundamentos.

O primeiro correspondeu à defesa da correta interpretação da referida Lei, para considerá-la como um regulamento geral da ação punitiva da administração pública no exercício do poder administrativo sancionador. Nessa perspectiva, sequer seria necessário fazer o uso da analogia, pois, devidamente interpretada, a norma não seria aplicável nos casos relacionados ao exercício do denominado poder administrativo de polícia (preventivo), mas, sim, do poder administrativo sancionador (repressivo). Para o Relator, as sanções administrativas estão sujeitas, em linhas gerais,

${ }^{9} \mathrm{O}$ acórdão foi aprovado por maioria, nos termos do voto do Relator, Min. Roberto Barroso, acompanhado pela Min. Rosa Weber, vencido o Min. Marco Aurélio e ausente o Min. Luiz Fux. Não obstante, nos termos de sua manifestação, o Min. Marco Aurélio acompanhou o entendimento majoritário em relação à aplicação da Lei n. 9.873/1999, divergindo apenas quanto à interrupção do prazo prescricional, por considerar que o prazo deveria ter fluído até a notificação do responsável para defender-se e não desde a apuração dos fatos, em relação à gestão como um todo, sem a ciência e integração do impetrante à relação processual administrativa que levou à sanção. 
a um único regime jurídico, um estatuto constitucional do poder punitivo estatal, a englobar os princípios da legalidade, do devido processo legal, do contraditório e da ampla defesa, da segurança jurídica e da irretroatividade, da culpabilidade e da pessoalidade da pena, da individualização da sanção, da razoabilidade e da proporcionalidade. Somou-se a esse argumento a interpretação histórica, ao destacar que a intenção do legislador, apurada na exposição de motivos da medida provisória que resultou na Lei aprovada, demonstrava que a referida regulamentação teria o condão de uniformizar a questão da prescrição no âmbito da administração pública federal.

O segundo fundamento, integrante do voto vencedor, residiu na aplicação analógica da Lei n. 9.873/1999, porque representaria a regulamentação mais adequada ao caso. Aqui o argumento da autonomia científica do direito administrativo é invocado para afastar a possibilidade de se recorrer às normas de direito civil em caso de lacunas. Cita, nesta esteira, diversas normas que têm como referência a adoção do prazo prescricional quinquenal no âmbito do direito administrativo ${ }^{10}$. Não obstante, os demais aspectos do regime prescricional, como o início do prazo e os marcos relacionados à interrupção ou suspensão do prazo, além da prescrição intercorrente, por não encontrarem a mesma uniformidade, justificariam, para o Relator, a adoção integral da Lei n. 9.873/1999, em vez de se criar um regime híbrido para tais casos.

Estabelecidas as premissas necessárias quanto à atuação dos Tribunais de Contas no exercício de sua competência sancionatória, as características gerais da prescrição e os entendimentos adotados no âmbito do Tribunal de Contas da União e do Supremo Tribunal Federal, deve-se passar ao ponto central deste trabalho, atinente aos critérios para superar lacunas normativas no âmbito do direito administrativo, em especial em relação ao regime jurídico da prescrição a ser adotado nas Cortes de Contas.

10 “[...] Decreto n. 20.910/32, art. 1'; CTN, arts. 168, 173 e 174; Lei n. 6.838/1980, art. $1^{\text {}}$; Lei n. 8.112/1990 ("Regime jurídico dos servidores públicos civis federais"), art. 142, I; Lei n. 8.429/1992, art. 23; Lei n. 8.906/1994 (Estatuto da OAB), art. 43; Lei n. 9.783/1999; Lei n. 12.529/2011 ("Lei antitruste”), art. 46; Lei n. 12.846/2013 ("Lei anticorrupção"), art. 25; entre outros.” (BRASIL, 2017, p. 9) 


\section{A Colmatação da Lacuna no Âmbito do Direito Público}

Inicialmente, é necessário analisar o primeiro argumento suscitado no âmbito do STF de que a Lei n. 9.873/1999 seria aplicável diretamente ao caso e não apenas por analogia. Se acolhida esta tese, não há que se falar em aplicação analógica, nem do Código Civil, nem da própria Lei n. 9.873/1999.

\subsection{A Impossibilidade de Aplicação Direta da Lei n. 9.873/1999 aos Tribunais de Contas}

Conforme assinalado anteriormente, ${ }^{11}$ os Tribunais de Contas não integram a administração pública. Eles não são órgãos do Poder Executivo, Legislativo ou do Judiciário, mas instituição autônoma e independente, que tem como parâmetro de organização o Poder Judiciário (art. 73, caput, parte final). Destarte, não se poderia aplicar diretamente norma cuja abrangência é restrita à administração pública federal (Poder Executivo) a outros Poderes (Legislativo e Judiciário) ou a órgãos autônomos e independentes, como o Tribunal de Contas e o Ministério Público.

Além desse aspecto, há outra questão que merece atenção, embora não se pretenda aprofundar no ponto, atinente ao vício de iniciativa de disposições oriundas de iniciativa parlamentar ou do Chefe do Executivo, mas que versem sobre matérias que repercutam diretamente na atuação dos Tribunais de Contas. A jurisprudência pacífica do STF, por interpretação sistemática dos artigos 73, 75 e 96, inc. II, da Constituição, firmou-se no sentido de que as Cortes de Contas seguem o exemplo dos tribunais judiciários, em relação às garantias de independência, sendo também detentoras de autonomia funcional, administrativa e financeira, disso decorrendo, essencialmente, a iniciativa reservada para instaurar processo legislativo que pretenda alterar sua organização e funcionamento (BRASIL, 2017b). Não seria possível, portanto, defender a aplicação direta da Lei n. 9.873/1999, cuja elaboração não teve origem em proposição oriunda de Tribunal de Contas, sob pena de se tratar de norma inválida por vício de iniciativa.

${ }^{11}$ V. seção 2 supra. 
Destarte, resta afastado o argumento relacionado à aplicação direta da Lei n. 9.873/1999, seja por seu âmbito de incidência estar restrito à esfera da administração pública, que não compreende os Tribunais de Contas, seja por se tratar de norma cuja aprovação não decorreu de proposição da própria Corte de Contas, fato que suscitaria o vício de iniciativa. Isto, contudo, não afasta a possibilidade de aplicação da referida norma por analogia, que é o fundamento a ser analisado a seguir.

\subsection{Lacuna de Regulação e a sua Colmatação pela Analogia}

Há, como visto, certo consenso em relação à necessidade de delimitação de um prazo prescricional para a atuação dos Tribunais de Contas no exercício de sua competência sancionatória, além dos demais aspectos relacionados à questão, como a definição do marco inicial de contagem do lapso temporal e suas causas interruptivas e suspensivas. Não se está, portanto, no denominado "espaço livre de Direito", mas diante daquilo que Karl Larenz (2012, p. 524-528) denomina "lacuna de regulação", concernente à ausência de regulamentação em conjunto - e não apenas para uma questão específica -, e cuja colmatação é necessária, depreendida do próprio "plano legislativo" da norma.

De fato, a Constituição dispõe sobre a imprescritibilidade das penalidades sempre de forma excepcional e expressa (v. art. $5^{\circ}$, inc. XLII e XLIV, e $37, \S 5^{\circ}$, da Constituição da República). Além disso, é inerente à Lei que institui e regulamenta determinada competência punitiva a delimitação dos limites temporais de atuação do órgão legitimado a aplicar a sanção. Em relação ao TCU, a possibilidade de aplicação de penalidades pecuniárias foi instituída nos artigos 56 e segs. de sua Lei Orgânica, (Lei n. 8.443/1992), que não limitou temporalmente essa competência. Neste caso, a "teologia imanente" da Lei, na linguagem de Larenz (2012, p. 531), aponta no sentido da colmatação dessa lacuna ${ }^{12}$. Essa lacuna deve ser qualificada como "patente" por ser inferida da própria regulação legal,

\footnotetext{
${ }^{12}$ Não se vislumbra no caso aqui retratado, portanto, uma "lacuna do Direito", reconhecida, por Larenz, nos casos em que uma lei em particular não está incompleta em relação ao seu plano regulador, mas, sim, a ordem jurídica em seu conjunto, quando o legislador deixa de regular todo um setor ou não prevê um instituto jurídico que deveria ter previsto (2012, p. 533-534).
} 
que deixou a questão do prazo prescricional para a cominação das multas em aberto (LARENZ, 2012, p. 537) ${ }^{13}$.

Larenz (2012, p. 540-541) reconhece a possiblidade de se recorrer à analogia para a integração das "lacunas patentes", a partir da "transposição de uma regra, dada na lei para a hipótese legal (A), ou para várias hipóteses semelhantes, numa outra hipótese $\mathrm{B}$, não regulada na lei, $<<$ semelhante $>>$ àquela". Para tal processo, a hipótese legal e a hipótese não regulada na lei deverão ser identicamente valoradas, em seus aspectos decisivos, sob fundamento na exigência de justiça, que impõe conferir tratamento igual àquilo que é igual (LARENZ, 2012, p. 541). Por se tratar de semelhança, por óbvio, as duas situações de fato não devem ser consideradas idênticas, mas concordantes em alguns aspectos, recorrendo-se aos fins e ideias fundamentais da regulação legal, é dizer, para a ratio legis (LARENZ, 2012, p. 541-542). Nesse contexto, à hipótese não regulamentada do prazo prescricional para aplicação de penalidades pelo Tribunal de Contas, cumpre identificar qual regra deve ser aplicada por analogia (hipótese legal), se aquelas decorrentes do direito privado ou do direito público.

Hartmut Maurer (2006, p. 61-63) destaca que a aplicação subsidiária de prescrições jurídico-privadas no direito administrativo pode ocorrer por força de declaração expressa do legislador ou por estar fundada na concepção de que existem princípios de direito gerais comuns ao direito público e privado, cujo conteúdo é apenas concretizado pelo Código Civil, a exemplo do princípio da lealdade e da boa-fé.

Além disso, para Maurer a aplicação dessas prescrições no âmbito do direito público também pode ser fundamentada pela analogia, estabelecendo como pressuposto, para tal finalidade, que

[...] uma prescrição correspondente falte no direito administrativo, a lacuna não possa ser fechada por invocação de prescrições jurídico-públicas e os pressupostos da analogia (semelhança dos fa-

\footnotetext{
${ }^{13}$ Larenz qualifica como "lacuna oculta" a situação em que o legislador estipula uma regra para determinados casos, mas não declara na lei uma restrição, exigida a partir da finalidade da norma (LARENZ, 2012, p. 537).
} 
tos em perspectiva jurídico-valorativa) existem. (MAURER, 2006, p. 62-63)

Reconhece que tais possibilidades - aplicação com fundamento nos princípios gerais ou por analogia - não são excludentes, existindo frequentemente dificuldades em reconhecer cada hipótese, embora a analogia prevaleça na maioria dos casos (MAURER, 2006, p. 63).

Um parâmetro delineado pelo autor consiste em reconhecer a possibilidade de princípios de direito gerais fundamentarem competências da administração, cuja ampliação não poderia ocorrer por analogia (MAURER, 2006, p. 63). Assevera ainda que, em regra, a analogia autoriza somente a remissão às consequências jurídicas e não aos fundamentos jurídicos, citando a custódia jurídico-pública no direito alemão, em que o Código Civil define como o objeto deve ser tomado em custódia, conservado e devolvido pela administração, mas são fundamentos de direito público que delimitam quando o sequestro e o asseguramento podem ocorrer (MAURER, 2006, p. 63).

A hipótese legal que melhor se amolda à hipótese não regulamentada do prazo prescricional para o exercício da competência sancionatória pelos Tribunais de Contas deve ser extraída, portanto, do âmbito do direito público, dada a maior aproximação - semelhança - da situação fática por ele regulamentada, mormente quando se trata, no caso, de uma atuação estatal pautada no exercício de um dever-poder estatal sobre um gestor público ou responsável, que poderá ser um particular ou agente público (v. art. 70, parágrafo único, da Constituição da República), mas jamais sujeitos em situação de igualdade, como se observa, em regra, no âmbito do direito privado. Aliás, como visto, um dos requisitos estabelecidos por Maurer para a aplicação das prescrições de direito privado no âmbito do direito público consiste justamente na impossibilidade de sua colmatação por invocação de prescrições jurídico-públicas, além da lacuna e da semelhança em perspectiva jurídico-valorativa (MAURER, 2006, p. 62-63). Conforme será demonstrado a seguir, há normas de direito público que permitem a sua aplicação por analogia ao caso estudado, sem a necessidade de se recorrer ao direito privado. 


\subsection{A Aplicação da Lei n. 9.873/1999 aos Tribunais de Contas por Ana- logia Legis}

Parcela da doutrina sustenta que cada ramo do direito material possui prazo de prescrição específico, dotado, inclusive, de princípios próprios, além de estarem devidamente previstos no direito positivo (BORGES, 2013, p. 8). Assim, as previsões normativas acerca da prescrição, provenientes de outros ramos do direito, não deveriam ser aplicadas aos processos em curso nos Tribunais de Contas, tendo em vista que tais normas possuem fundamentos e premissas diversos dos que orientam os processos específicos das Cortes de Contas. Alguns autores sugerem uma ordem para a transposição das normas, observando, inicialmente, as de direito administrativo, direito tributário, direito penal e, apenas excepcionalmente, quando as anteriores silenciarem, as de direito privado (FERNANDES, 2003, p. 563).

A rigor, a Lei de Introdução ao Direito brasileiro prevê, nos casos de lacuna, que a decisão seja pautada pela analogia, pelos costumes e pelos princípios gerais do direito (art. $4^{\circ}$ do Decreto-Lei n. 4.657/42). Para aplicar a analogia é fundamental que os fatos aos quais a mesma regra é aplicada sejam semelhantes e identicamente valorados (LARENZ, 2012, p. 541), conforme destacado anteriormente ${ }^{14}$. Nesse sentido, é inegável que as relações jurídicas entre os particulares não guardam as mesmas especificidades das relações havidas com o poder público. Os princípios da supremacia do interesse público sobre o privado e o da indisponibilidade, pela Administração, do interesse público, que caracterizam o regime jurídico-administrativo (MELLO, 2003, p. 45-50), embora atualmente mereçam certa revisão (BINENBOJM, 2008, p. 29-33; SUNDFELD, 2012, p. 47; JUSTEN FILHO, 2010, p. 62-63) ${ }^{15}$, permitem, em linhas gerais, demonstrar algumas das particularidades que caracterizam a relação entre o Estado e o particular.

A partir dessa sistematização, surgem as ideias de posição privilegiada da Administração, a fim de bem assegurar o interesse público, da qual decorrem alguns privilégios, como a presunção de veracidade e de

\footnotetext{
${ }^{14} \mathrm{~V}$. subseção 6.2 .

${ }^{15}$ Não é o escopo deste artigo fazer um exame aprofundado do tema.
} 
legitimidade dos atos administrativos, benefício de prazos judiciais maiores e prazos especiais para prescrição (MELLO, 2003, p. 60-64). Há, ainda, a posição de supremacia, traduzida na relação de verticalidade nas relações entre os particulares e a Administração, a possibilitar a constituição dos particulares em obrigações por meio de atos unilaterais, bem como a modificação unilateral de relações já estabelecidas (MELLO, 2003, p. 60-64).

Da conjugação dessa posição privilegiada com a posição de supremacia resulta, na lição de Celso Antônio Bandeira de Mello (2003, p. 60-64), a exigibilidade dos atos administrativos - droit du préalable e, em alguns casos, a executoriedade, também denominada de execução de ofício. Por certo, tais prerrogativas não podem ser exercitadas como os particulares exercitam seus direitos, por serem poderes instrumentais ao alcance das finalidades, sem os quais não teria como se desincumbir do dever posto a seu cargo.

Não obstante às críticas que a caracterização do regime jurídico administrativo a partir da ideia do interesse público possa merece nos dias atuais, cumpre registrar que o autor dessas ideias, no Brasil, sempre defendeu o interesse público como um conceito jurídico-positivo. É dizer, por ser um conceito jurídico, a concreta individualização dos diversos interesses qualificáveis como públicos só poderia ser encontrada no próprio Direito Positivo. Assim, o interesse público não seria a norma, medida ou providência que uma pessoa ou grupo estime que deva ser, mas aquele interesse como tal qualificado em dado sistema normativo (MELLO, 2003, p. 58-60). Nessa senda, a referida ideia não conflita, mas, ao contrário, caminha ao encontro da imperiosa proteção dos direitos fundamentais que caracteriza nossa Constituição. Noutras palavras, a ideia de interesse público não se sobrepõe aos direitos fundamentais, mas o interesse público deve ser resguardado tendo em mente a proteção de tais direitos.

Feita essa ressalva, cumpre acentuar, pois, que o regime jurídico administrativo guarda peculiaridades em relação ao regime de direito privado, a atrair, em caso de lacuna normativa, as regras afeiçoadas ao regime público. Neste passo, é no regime de direito público que se deve buscar, por analogia, as normas a serem aplicadas ao problema proposto neste trabalho. 
Ademais, entende-se que, por imperativo do princípio da legalidade, que rege com especial densidade as relações jurídico-administrativas, independentemente do prazo prescricional adotado deve-se utilizar o regime jurídico relativo à prescrição por inteiro, inclusive no que se refere às causas de suspensão e interrupção. É dizer, à falta de norma específica, não se pode invocar apenas as normas que estabelecem o prazo prescricional, olvidando-se das outras correlatas que definem suas causas de interrupção e/ou prescrição. Mesclar regimes jurídicos diversos ensejaria, ao final, diante da abundância de normas relacionadas ao tema da prescrição no âmbito administrativo, o exercício indevido da atividade legislativa por via transversa.

Estabelecidas as referidas premissas, resulta mais consentâneo com o regime jurídico aplicável aos Tribunais de Contas, mormente no exercício de sua competência sancionatória, a aplicação, por analogia, das normas de direito público. No caso das multas decorrentes do descumprimento de suas determinações ou daquelas em razão da violação de normas legais ou regulamentares, as normas de direito público mais próximas e que regulamentam em todos os aspectos a questão seriam aquelas previstas na Lei n. 9.873/1999, que estabelece o prazo de prescrição quinquenal para o exercício de ação punitiva pela administração pública federal.

Importante asseverar que, no âmbito do direito público, diversas normas tomam como parâmetro o prazo de cinco anos para fins de prescrição ou decadência. É o caso, por exemplo, do Decreto n. 20.910/1932, que prevê a prescrição quinquenal relativa às dívidas do poder público; da prescrição quinquenal para aplicar as sanções por improbidade administrativa previstas na Lei n. 8.429/1992; e do prazo decadencial de cinco anos para a administração anular seus atos, nos termos da Lei n. 9.784/1999, que regula o processo administrativo no âmbito federal, dentre várias outras.

A propósito da utilização do referido prazo, o Supremo Tribunal Federal (2011), ao apreciar a necessidade de instaurar o contraditório e a ampla defesa no âmbito dos processos relativos ao exame de legalidade dos atos concessivos de aposentadorias, reformas e pensões, considerou 
o lapso de cinco anos como um prazo médio razoável para a atuação dos Tribunais de Contas.

A utilização da Lei n. 9.873/1999, no caso das multas aplicadas pelos Tribunais de Contas é adequada não apenas por estabelecer o prazo de cinco anos em consonância com diversas outras normas de direito público, mas por tratar especificamente das hipóteses de prescrição da ação punitiva, relativa ao prazo para apuração da infração cometida, inclusive da prescrição intercorrente, nos seus artigos $1^{\circ}$ e $2^{\circ}$, bem como do prazo de prescrição da ação executória, pertinente ao tempo hábil para o ajuizamento da respectiva ação voltada à execução da dívida, em seus artigos $1^{\mathrm{a}}$-A e $2^{\mathrm{o}}$-A.

Tal disciplina guarda incomum compatibilidade com a realidade dos Tribunais de Contas, que precisam ter a definição clara de um prazo para apurar as infrações eventualmente cometidas pelos seus jurisdicionados e de outro prazo para o momento posterior quando, apurada a infração e aplicada a penalidade, o jurisdicionado não adimple espontaneamente a obrigação. É dizer, nesse segundo caso, um prazo para que a Corte providencie a execução judicial das multas aplicadas aos responsáveis e não pagas.

Outra razão em prol da aplicação referida da lei consiste na previsão que faz, também, em relação às causas de interrupção e de suspensão do prazo prescricional, imprescindíveis para a racionalidade da contagem do lapso temporal, além de regras específicas tratando da denominada prescrição intercorrente, inexistentes no âmbito do Código Civil.

Destarte, são aplicáveis, por analogia, aos Tribunais de Contas, com as devidas adaptações, as disposições da Lei n. 9.873/1999, tratando-se, pois, de uma "analogia legis" ou "analogia particular", conforme ensina Larenz, por tratar-se da aplicação de uma norma legal particular a uma situação fática por ela não regulamentada, dada a semelhança entre a hipótese legal e a hipótese não regulamentada (LARENZ, 2012, p. 544). 


\subsection{Análise Prática da Aplicação da Lei n. 9.873/1999 aos Tribunais de Contas}

A fim de adaptar as referidas regras à realidade dos Tribunais de Contas, temos que o marco que caracteriza o crédito decorrente de multa como devidamente constituído é o da decisão final de que ela resultar. A partir do decurso do prazo recursal já há a possibilidade de ajuizamento de ação de execução, dada a eficácia de título executivo da qual são dotadas todas as deliberações das Cortes de Contas, por força do $\S 3^{\circ}$ do art. 71 da Constituição. Despicienda, portanto, a inscrição das multas aplicadas por Tribunais de Contas na dívida ativa, senão para fins de controle, posto que já dotadas de força executiva.

Dessa forma, antes da decisão final do Tribunal temos o prazo prescricional para a ação punitiva, voltado à apuração da infração, que se inicia a partir da data da prática do ato ou no dia em que cessar, se for infração permanente ou continuada ( $\operatorname{art} .1^{\circ}$ ). Após a decisão final da Corte tem início o prazo prescricional para o ajuizamento da ação executória (art. $1^{\mathrm{O}}$-A). Os dois prazos são quinquenais. Nesse ínterim, há a possibilidade de ocorrência da prescrição intercorrente, em caso de paralisação do feito por mais de três anos, pendente de julgamento ou despacho, sem prejuízo da apuração da responsabilidade funcional decorrente desta paralisação $\left(\operatorname{art.} 1^{\mathrm{a}}, \S 1^{\circ}\right)$. São aplicáveis, ademais, as regras referentes à interrupção e suspensão da prescrição (artigos $2^{\circ}, 2^{\circ}$-A e $3^{\circ}$ ), como as que estabelecem a interrupção da prescrição pela notificação ou citação do responsável, ou pela prática de qualquer ato inequívoco que importe a apuração do fato.

\section{Conclusão}

A questão do transcurso do tempo no âmbito das Cortes de Contas vem suscitando várias controvérsias, em razão da ausência, em diversos Tribunais, de normas que disciplinem especificamente o regime jurídico da prescrição em seu âmbito. O STF já teve a oportunidade de se manifestar, em alguns casos, em relação aos efeitos da inércia dos Tribunais de Contas no exercício de seu mister, tanto em hipóteses em que havia norma expressa definindo prazos para atuação, quanto noutras situações em 
que tal previsão era inexistente. Há, ainda, outras demandas em trâmite sobre o tema.

Neste trabalho o objetivo consistiu especificamente em definir a questão relacionada à submissão da competência sancionatória dos Tribunais de Contas a algum prazo prescricional, nos casos em que não exista norma expressa disciplinando a situação, como ocorre no âmbito do Tribunal de Contas da União.

A competência para aplicar sanções é prevista pela Constituição e os Tribunais de Contas, via de regra, possuem em suas leis orgânicas a tipificação de condutas sujeitas a penalidades pecuniárias. Não se observa com a mesma frequência, no entanto, a previsão expressa de prazo para a atuação do órgão de fiscalização. Compreender que tal omissão autorizaria a atuação a qualquer tempo redundaria em considerar como imprescritíveis a cominação e a execução das multas, em descompasso com o texto constitucional.

Considerando as peculiaridades do regime jurídico-administrativo, pautado nos princípios da supremacia do interesse público sobre o privado e na indisponibilidade, pela Administração, do interesse público, que o diferencia do regime de direito privado, conclui-se que se deve aplicar, por analogia legis, nos termos do artigo $4^{\circ}$ da Lei de Introdução ao Direito Brasileiro, as regras do direito público.

Destarte, a cominação de multa pelos Tribunais de Contas está sujeita ao prazo prescricional quinquenal, lapso este considerado por diversas normas de direito público e pelo próprio Supremo Tribunal Federal como um prazo razoável para a atuação do controle externo.

Pelas peculiaridades da atuação sancionatória pelos Tribunais de Contas, em especial pela necessidade de se estabelecer um marco temporal para a atuação do controle externo, a contar da ocorrência das condutas ilícitas tipificadas em lei, e outro prazo para a execução do crédito decorrente da multa, além de se estabelecer critérios para a contagem da prescrição intercorrente, tem-se na Lei n. 9.873/1999 o marco legal mais adequado para aplicação da prescrição, no que for cabível, aos processos de contas voltados à cominação de penalidade pecuniária. 


\section{Referências}

BRASIL. Constituição da República Federativa do Brasil de 1988.

Disponível em: $<$ http://www.planalto.gov.br/ccivil_03/constituicao/ constituicao.htm>. Acesso em: 25 ju. 2018.

BRASIL. Ministério Público Federal. Parecer n.

182.786/2015-AsJConst/SAJ/PGR. Procurador-Geral da República Rodrigo Janot Monteiro de Barros. Brasília, 16 set. 2015. Disponível em: $<$ http://www.stf.jus.br/portal/processo/verProcessoAndamento.asp?nume ro $=5259$ \& classe $=$ ADI\& codigoClasse $=0$ \& origem $=J U R \&$ recurso $=0 \&$ tipo Julgamento=M $>$. Acesso em: 9 dez. 2017.

BRASIL. Supremo Tribunal Federal. Acórdão no mandado de segurança n. 32201. Relator Min. Roberto Barroso, Primeira Turma, 21 mar. 2017. Diário da Justiça Eletrônico, 4 agosto, 2017a.

BRASIL. Supremo Tribunal Federal. Acórdão na ação direta de inconstitucionalidade n. 4418. Relator Min. Dias Toffoli. Brasília, Tribunal Pleno, 15 dez. 2016. Diário da Justiça Eletrônico, 17 março, $2017 \mathrm{~b}$.

BRASIL. Supremo Tribunal Federal. Acórdão na ação direta de inconstitucionalidade n. 3077. Relatora Min. Carmen Lúcia. Brasília, Pleno, 16 nov. 2016. Diário da Justiça Eletrônico, 21 novembro, 2016 a. BRASIL. Supremo Tribunal Federal. Acórdão no recurso extraordinário n. 636886 RG. Relator Min. Teori Zavascki. Brasília, Plenário Virtual, 2 jun. 2016. Diário da Justiça Eletrônico, 15 junho, 2016b.

BRASIL. Supremo Tribunal Federal. Acórdão no recurso extraordinário n. 669069. Relator Min. Teori Zavascki. Brasília, Tribunal Pleno, 3 fev. 2016. Diário da Justiça Eletrônico, 28 abril, 2016c.

BRASIL. Supremo Tribunal Federal. Acórdão nos segundos embargos de declaração no mandado de segurança n. 25116. Relator Min. Teori Zavascki. Brasília, Tribunal Pleno, 22 maio 2014. Diário da Justiça Eletrônico, 13 junho, 2014. 
BRASIL. Supremo Tribunal Federal. Súmula Vinculante n. 3. Nos processos perante o Tribunal de Contas da União asseguram-se o contraditório e a ampla defesa quando da decisão puder resultar anulação ou revogação de ato administrativo que beneficie o interessado, excetuada a apreciação da legalidade do ato de concessão inicial de aposentadoria, reforma e pensão. Brasília, Pleno, 30 maio 2007. Diário da Justiça Eletrônico, 6 junho, 2007.

BRASIL. Supremo Tribunal Federal. Acórdão no mandado de segurança n. 24.510. Relatora Min. Ellen Gracie. Brasília, Tribunal Pleno, 19 nov. 2003. Diário da Justiça Eletrônico, 19 março, 2004.

BRASIL. Tribunal de Contas da União. Acórdão n. 1781/2017. Relator Min. José Múcio Monteiro, Plenário, 16 agosto, 2017a.

BRASIL. Tribunal de Contas da União. Acórdão n. 851/2017. Relator Min. Aroldo Cedraz, Plenário, 3 maio, 2017 b.

BRASIL. Tribunal de Contas da União. Acórdão n. 374/2017. Relator Min. Bruno Dantas. Brasília, Plenário, 8 março, 2017c.

BRASIL. Tribunal de Contas da União. Acordão n. 1441 no incidente de uniformização de jurisprudência do processo 030.926/2015-7. Relator Min. Benjamim Zymler. Brasília, Pleno, 8 junho, 2016.

BINENBOJM, Gustavo. Uma teoria do Direito Administrativo: direitos fundamentais, democracia e constitucionalização. Rio de Janeiro: Renovar, 2008.

BORGES, Maria Cecília. Algumas reflexões acerca do princípio da segurança jurídica no exercício do controle externo pelos Tribunais de Contas diante das dificuldades decorrentes do volume processual e ineficiência - Inaplicabilidade da prescrição e da decadência e apresentação de alternativas para racionalização administrativa e razoável duração dos processos nas Cortes de Contas. Interesse Público - IP, Belo Horizonte, ano 15, n. 78, mar./abr. 2013.

BRITTO, Carlos Ayres. O Regime Constitucional dos Tribunais de Contas. Fórum Administrativo - FA, Belo Horizonte, ano 5, n. 47, jan. 2005. 
CAVALCANTI, Augusto Sherman. O processo de contas no TCU: o caso do gestor falecido. Revista do Tribunal de Contas da União, Brasília, n. 81, p. 17-27, jul./set. 1999. Disponível em: <http://revista.tcu.gov.br/ ojsp/index.php/RTCU/article/view/1122>. Acesso em: 14 set. 2016.

FAGUNDES, M. Seabra. O controle dos atos administrativos pelo Poder Judiciário. Atualizada por Gustavo Binenbojm. 7. ed. Rio de Janeiro: Forense, 2005.

FERNANDES, J. U. Jacoby. Tribunais de Contas do Brasil Jurisdição e Competência. 5. ed. Belo Horizonte: Fórum, 2003.

FERRAZ, Luciano. Poder de coerção e poder de sanção dos Tribunais de Contas - competência normativa e devido processo legal. Revista Diálogo Jurídico, Salvador, Centro de Atualização Jurídica (CAJ), n. 13, abril-maio, 2002. Disponível em: <http://www.direitopublico.com.br $>$. Acesso em: 18 dez. 2014.

FILHO, Agnelo Amorim. Critério Científico para distinguir a prescrição da decadência e para identificar as ações imprescritíveis. Revista dos Tribunais, [S.l.], v. 744, p. 725-50, 1997.

FINCATO, Denise. A pesquisa jurídica sem mistérios: do projeto de pesquisa à banca. 2. ed. Porto Alegre: Sapiens, 2014.

GONÇALVES, Carlos Roberto. Direito Civil Brasileiro. 4. ed. São Paulo: Saraiva, 2007. v. I.

JUSTEN FILHO, Marçal. Comentários à Lei de Licitações e Contratos Administrativos. 14. ed. São Paulo: Dialética, 2010.

LARENZ, Karl. Metodologia da Ciência do Direito. 6. ed. Tradução José Lamego. Lisboa: Fundação Calouste Gulbenkian, 2012.

LÔBO, Paulo Luiz Netto. Direito Civil: Parte Geral. São Paulo: Saraiva, 2009.

MAURER, Hartmut. Direito Administrativo Geral. 14. ed. Tradução Luís Afonso Heck. Barueri: Manole, 2006.

MELLO, Celso Antônio Bandeira de. Curso de Direito Administrativo. 15. ed. São Paulo: Malheiros, 2003. 
MELLO, Marcos Bernardes de. Teoria do Fato Jurídico: Plano da Existência, 1. ed. São Paulo: Saraiva, 2007.

MEZZAROBA, Orides; MONTEIRO, Cláudia Servilha. Manual de metodologia da pesquisa no direito. 6. ed. São Paulo: Saraiva, 2014.

MIRANDA, Francisco Cavalcanti Pontes de. Comentários à

Constituição de 1967 com a Emenda n. 1 de 1969. 2. ed. São Paulo: Revista dos Tribunais, 1973.

SUNDFELD, Carlos Ari. Direito Administrativo para céticos. São Paulo: Malheiros, 2012.

THEODORO JÚNIOR, Humberto. Distinção científica entre prescrição e decadência. Um tributo à obra de Agnelo Amorim Filho. In: DIDIER JR., Fredie; MAZZEI, Rodrigo. Reflexos do Novo Código Civil no Direito Processual. 2. ed. Salvador: Editora Juspodivm, 2007.

Marcos Ehrardt Junior é doutor pela Universidade Federal de Pernambuco (UFPE). Mestre em Direito pela Universidade Federal de Alagoas (UFAL). Professor de Direito Civil da UFAL. Professor de Direito Civil e Direito do Consumidor do Centro Universitário CESMAC. Pesquisador Visitante do Instituto Max-Planck de Direito Privado Comparado e Internacional (Hamburgo/ Alemanha). Líder do Grupo de Pesquisa Direito Privado e Contemporaneidade (UFAL). Membro do Grupo de Pesquisa Constitucionalização das Relações Privadas (CONREP/UFPE). Editor da Revista Fórum de Direito Civil (RFDC). Diretor Nordeste do Instituto Brasileiro de Direito Civil (IBDCIVIL). Membro do Instituto Brasileiro de Direito de Família (IBDFAM) e do Instituto Brasileiro de Estudos de Responsabilidade Civil (IBERC). Advogado.

E-mail:marcosehrhardtjr@uol.com.br.

Endereço: Av. Professor Vital Barbosa, n. 882, Apto. 402, Ponta verde, Maceió, AL. CEP: 57035-400.

Ricardo Schneider Rodrigues é doutorando em Direito pela Pontifícia Universidade Católica do Rio Grande do Sul (PUC/RS). Mestre em Direito 
Público pela Universidade Federal de Alagoas (UFAL). Especialista em Direito Processual Civil pela Universidade Anhanguera. Especialista em Direito Tributário pela Universidade do Sul de Santa Catarina. Professor Titular de Direito do Centro Universitário CESMAC (graduação e pós-graduação). Procurador do Ministério Público de Contas do Estado de Alagoas.

E-mail: prof.ricardo.schneider@gmail.com.

Endereço: Av. Fernandes Lima, 1047, Farol, $2^{\circ}$ andar, Maceió, AL. CEP: 57055903. 